\title{
"CHURCH BOUNDARIES" AND CANONICAL TERRITORY IN THE CONTEXT OF THE AUTOCEPHALIC SYSTEM OF UNIVERSAL ORTHODOXY
}

The article analyzes the fundamental problem of the corpus of ecclesiastical law - the autocephalous principle of the existence of the church. The study found that since the time of the Byzantine Empire, state power imposed its own principle of administrative division and management methods. Already in the II-III centuries, a clear hierarchical structure of church government has been formed. It is specified that the foundation of the first apostolic communities took place exclusively on the basis of the autocephalous principle. It is determined that the institution of autocephaly has been through a difficult path of formation: from the basic state of existence to a church-political phenomenon.

It has been proved that it is the autocephalous system that is the only acceptable version of the existence of the Ecumenical Orthodoxy. Therefore, the struggle of a number of national churches for its independence and recognition is fair. The absence of a clear regulation of the procedure for proclaiming a new autocephalous church is specified.

It is established that the principle of having a "canonical territory" in each of the churches was constantly violated. This is due to the problem of "parallel jurisdictions". The problem has been arising after the Fourth Ecumenical Council, when parallel hierarchies has been formed on the same territory. Nowadays, the problem of "parallel jurisdictions" is particularly acute in Western Europe and the American continents.

The article establishes that the institutional disputes of the Local Churches, related to the borders and the "canonical territory", can be resolved only in a conciliar way and with the participation of all Orthodox hierarchs. Existing approaches to solving the "temporary" problem of "parallel jurisdictions" have led to the incorporation of existing non-canonical entities into recognized churches.

The study emphasizes that the borders of the "canonical territory" in the vast majority should coincide with state borders, given that the state is politically sufficient, strong and constitutionally capable of supporting the church. Therefore, the church needs to return to the initial moment of institutional formation, when church borders corresponded specifically to national borders rather than territorial ones.

Keywords: church, orthodoxy, canon, council, metropolitan, autocephaly, ecclesiology, diaspora.

In recent years, the Orthodox Church has been at the center of a large-scale confrontation and global misunderstanding. Preparations for the Great Council, which was partially undermined (Crete, 2016), constant struggle for supremacy in the system of autocephalous churches and granting of the Tomos for Ukraine, caused a significant global response. The dissolution of the Eucharistic communion between several Local Churches in 2019 only exacerbated the conflict. The situation around the recognition of the "canonicity" of the decision of the Ecumenical Primate regarding the Ukrainian Church becomes especially acute. For example, these days in Cyprus, a number of hierarchs have refused to concelebrate with High Hierarch Chrysostom due to the prayerful remembrance of Metropolitan Epiphanius. In other churches, on the contrary, some hierarchs support the recognition of the Orthodox Church of Ukraine, while the Synod and the Primate are against it. Thus, the situation in Orthodoxy is complex and disputed. There is no short-term prospect of leveling it yet.

One of the key reasons for the multi-vector of the Orthodox Church is the lack of a unified approach to understanding the autocephalous structure. It was in Crete in 2016 that the landmark document "Autocephaly and the ways of its proclamation" was to be adopted, however, due to the absence of four Local Churches, the key documents never received a general resolution. Autocephaly is one of the basic institutions of the church, which has been inherent in it since its inception. No doubt, the understanding of autocephaly as a church institution has been changed significantly over two thousand years of history, as has the very status of autocephalous churches. However, even today this is a fundamental principle of admin- istrative management, which follows from the very ecclesiological nature of the church.

The relevance of scientific research lies in highlighting the central problem of the modern church - the administrative structure. Autocephalous status and the possibility of acquiring it have always been the cornerstone of theological debates. The boundaries of jurisdiction and the "canonical territory" are increasingly causing misunderstandings between the Local Churches.

In general, autocephalous issues and the concept of canonical territory, which has been popular in recent years, are important and interesting not only for specialists, but also for the general public of those who are interested in religious issues, in particular in Ukraine. Granting of the Tomos for the Ukrainian Church has significantly raised the bar of public interest in church issues. In addition, this event caused a great resonance in the world and profound theological discussions. Today, only some of the Local Churches have recognized this act as legitimate. Moreover, the relevance of the topic is exacerbated by the fact that there are a number of national churches that also seek their own universal recognition (Montenegrin, Macedonian Orthodox Churches).

The purpose of the article is to shed light on the question of the boundaries of the jurisdiction of a particular Local Church in the context of the ecclesiological conditionality of the autocephalous system of world Orthodoxy. The very nature of the church, according to Orthodox ecclesiology, must be independent of any attempts to usurp church authority. Therefore, the study focuses on the very phenomenon of the Church in its historical retrospect.

The state of scientific development of the chosen topic is ambiguous. Hundreds of speeches, public statements 
and official letters of theologians and hierarchs of various Local Churches on autocephalous issues have a pronounced confessional nature. Controversy between representatives of different churches leads to distortions and twisted interpretations of canons and historical church practice. In general, with the proclamation of each new autocephaly in Orthodoxy, discussions on the right of primacy of the Ecumenical Throne and unification in the context of resolving this issue has been intensified. At the same time, the signing of the new Tomos for Ukraine also attracted the attention of secular scholars from around the world.

The classical basis for substantiating the problem of the autocephalous system and the canonical territory is revealed in the works of such famous Ukrainian researchers and canonists as I. Vlasovsky, O. Kyridon, O. Lototsky, Y. Mulyk-Lutsyk and others, who repeatedly drew attention to the process of emergence of the institution of autocephaly. This should also include world-renowned scientists: V. Asmus, D. Bingham, A. von Harnack, J. Hoffmann, J. Ziziulas, I. Isichenko, J. Robertson, A. Kartashev, E. Caesarea, N. Milash, E. Smirnov, S. Smirnov, K. Skurat, K. Ware, F. Uspensky and others.

The importance and relevance of the chosen topic is evidenced by a number of modern dissertation researches, for example, of V. Butynsky, M. Gergelyuk, A. Didkovsky, E. Zaremba. The works of the Ukrainian scientist Archimandrite Cyril (Govorun), who is one of the best theologians in modern Orthodoxy, are particularly important and profound. He clearly reveals the essence of the transformation of the ecclesiological conditionality of the modern church structure and the problem of the limits of jurisdictional powers.

V. Bolotov's four-volume book on the history of the formation of the ancient Church is a fundamental research on the chosen topic. O. Lototsky's two-volume book reveals the very essence and principles on which autocephaly should be based. Also, a special place in the system of knowledge about autocephaly and the canonical territories of the church is occupied by a detailed study of the modern American scholar C. Sanderson "Autocephaly as a Function of Institutional Stability and Organizational Change in the Eastern Orthodox Church". The author offers his own approach to the autocephalous principle of the administrative system of the Orthodox Church. It consists in transforming the territorial principle of the formation of church administrations into a national one.

Thus, on the one hand, a significant scientific and theological aspect of the relevance of this issue and the presence of a number of fundamental works can be stated. On the other hand, the problem of acquiring autocephalous status and clear definition the boundaries of the canonical territory of influence remains open. There is no clear connection in the scientific works between the ecclesiological model of the ideal church of Christ and the modern administrative structure of church life. The presence of a number of little-studied scientific problems concerning the autocephalous arrangement of the Ecumenical Church significantly actualizes the chosen topic.

Autocephaly is the first basic institution of functioning and arrangement of church communities. On the one hand, it is archaic, and on the other hand, it has preserved, albeit in a transformed form, its significance in modern Orthodoxy. Characteristically, that in different historical periods the church considered this institution in a new way. From the natural state of existence, to the privileged political status. Professor Archimandrite Cyril (Govorun) claims, and one should agree with his opinion, that during each period the church have been invented the institution of autocephaly as a new one, only similar to previous iterations [5, p. 38].
The very idea of autocephaly had no special justification, no one invented or substantiated it. It existed simultaneously with the first communities. The communities that had been founded by the apostles did not report to anyone except the apostles themselves, and were completely selfsufficient. Complete equality between such communities is a particularity of early Christian period. However, over time and the spread of Christianity, the church took over the imperial form of government and administrative division. Depending on the location site, more and less privileged communities have been formed. The last ones become dependent on the first ones.

At the end of the third century, only some privileged churches retained autocephaly due to political influence and administrative significance in the empire. Instead, the remaining autocephalous churches were to regulate the administrative and ecclesiastical life of their dependent communities. First of all, it concerns the ordination of new bishops. Over time, some communities, such as the Church of Carthage, have lost their independence. Thus, in the early Christian period there is a transition from the basic state of the autocephalous system, to the privileged one. Only a few churches remained autocephalous, which were located in the largest administrative centers of the empire. Thus, a clear hierarchical structure of the church has been formed, which had not been inherent in it from the moment of its foundation. It should be noted that autocephaly has been transformed from an exclusively church phenomenon into a church-political one. In fact, it has remained so to this day [5, p. 38].

Today, the structure of the Ecumenical Church looks quite organized from the outside, as any textbook on the history of the church, or an article on the current state of Orthodoxy is unambiguous. Now there are separate Local Churches, the territory of which is specifically defined, and they are completely independent from each other. However, this situation only from the outside. In fact, there are a number of unresolved issues that globally undermine the functioning of the Orthodox Church, whose main mission is to care for human souls. The first and probably the most difficult issue, which is the quintessence of all other problems, is the number of mutually recognized churches. First of all, it must be clearly understood that there is no unanimous ecclesiological understanding of the structure of the Ecumenical Church. Currently, there are two approaches: Greek and Slavic (Moscow). The first approach advocates the principle of having a certain "gathering point" and coordination of churches - the Ecumenical Patriarchate, which regulates Orthodox life of other Local churches. The second - convinces that the Local Churches are completely independent, and any decisions of world scale can be made only at the General Council [6, p. 67]. That is why the problem of obtaining the status of autocephaly arose. Thus, the proclamation of independence of the Autocephalous Church of America was recognized by only a few Churches. The signing of the Tomos for the Ukrainian Church at the end of 2019 is considered a legitimate act so far only by four Local Churches. Therefore, even in terms of quantity, it is impossible to give an unambiguous answer today. A number of churches around the world, such as the Macedonian and Montenegrin, are fighting for their own recognition.

The next fundamental question that expresses the essence of all conflicts in modern Orthodoxy is the clear definition of the boundaries of the jurisdiction of each church. This is connected with the relatively new principle of ecclesiastical demarcation, which in modern theology is called a "canonical territory". There is currently no clear definition of this term due to its absence in modern religious dictionaries. However, this concept is considered to 
appear as the specific territorial boundaries of the Local Church, which are completely under its control and fall within its unique jurisdiction.

Understanding, and most importantly the correct application of this principle is essential for an interchurch dialogue. From the history of the formation of the early church, it becomes obvious the formation of a clear hierarchical structure, as mentioned above. The general model of government was reduced to the principle of "one city - one bishop - one church." Thus, already in the first centuries, clearly defined area has been bonded to a particular bishop. Without the permission of the senior bishop of the diocese or province, another bishop could not perform sacred acts at the same land. The modern understanding of the principle of a "canonical territory" is based exactly on this principle. Although this topic is not directly raised in Scripture, its ecclesiological understanding stems from the administrative structure of the early church. It is important to state, that such an understanding of the church hierarchy was not artificially invented. It comes naturally. After the apostolic preaching "to all tongues" an extensive system of individual communities has been formed. There is a need for a "permanent priesthood." Canonist Nikodim (Milos) indicates in the comments to the "Apostolic Rules" that with the formation of the first church regions (dioceses), it became necessary to determine the territory of each of them [8, p. 74].

The 17th rule of the Fourth Ecumenical Council fixes the general norm of the ratio of church territory to state distribution of administrative management. The rule states that after a city has been established, the division of parishes should follow civil and land orders. This rule has finally confirmed the identity of the church and state delimitation into administrative units. Therefore, bishops who had chairs in cities of political importance received considerable privileges. This was the reason for the formation of ancient patriarchates, as the capital cities had a relatively independent status [7, p. 128]. Thus, the very way of church life has changed.At an early stage, individual churches and communities communicated with each other solely on the basis of love. Over time, the institution of hierarchical management has been formed. It wasn't touching the church norms of internal life established by God, but it was regulating and coordinating the system of inter-community interaction. This happened in the process of forming the first dioceses, and especially metropolitan areas. The external aspects of the church life have changed, church began to use ordinary human law for internal relationships [7, p. 136]. The church and the state were reduced to a common denominator, especially under Justinian. This significantly deepened the hierarchy of the internal church component by analogy with the power structures of the empire.

Ancient "apostolic canons", as well as other documents of the early period, testify to the inadmissibility of violating the above principle. In particular, here are the main claims of the "canons": a bishop cannot ordain outside the parish (Canon 35), a bishop cannot move to another parish by his own will (Canon 14), the clergyman, without the will of the bishop, cannot move to another parish, otherwise he loses his dignity (Canon 15) and so on [4]. Such exact postulates were later enshrined in the canons of the Ecumenical and Local Councils. Obviously, these statements have not lost its canonical weight today.

It is important to know, that the early church took over the administrative system of the empire, which was based on the territorial principle of division. It was this method of forming diocesan churches that was optimal at the early stage of the formation of church legislation. Thus, the prototype of the "canonical territory" is found at the very origins of church canonism. The church had been existing in such conditions until the end of the 19th century, when the principle of church jurisdiction and the question of the boundaries of the church became relevant again due to the growth of a new phenomenon of the "Orthodox diaspora". Prior to that, it was clear that the jurisdiction, i.e. "canonical territory", for example, of the Church of Alexandria is the territory of Africa, of the Church of Antioch - Syria and Lebanon. The history of the church knows a significant number of cases when the boundaries of church jurisdiction has been violated, but the phenomenon of the diaspora has posed completely new ecclesiological challenges to the Orthodox community.

Significant geopolitical changes and wars of the late XIX - early XX centuries have changed the situation in the world dramatically. The collapse of powerful empires redistributed the spheres of influence of the Orthodox Churches into separate territories. A number of national churches, such as Helladian, Bulgarian, and Polish, received autocephalous status, thus reducing the territorial jurisdiction of the chiarchal (mother) churches. Labor, political and economic migration of the population led to the formation of entire dioceses in non-Orthodox territories. The "scattering people" raised in a new way the question of the ecclesiological boundary of the church and the observance of the principle of the "canonical territory".

The assertion of the principle of "parallel jurisdictions" caused a worldwide resonance, because it directly violated the ancient hierarchical postulate "one city - one bishop one church." The diaspora has become an alternative form of organization of the church system. Although it contradicted the traditions of the church, it was justified by the special historical conditions that prevailed in the twentieth century. Local Orthodox churches could not coordinate their joint activities in time due to political instability, constant military conflicts and revolutionary changes. Therefore, they were forced to respond to the requests of the flock and create church structures in the diaspora independently of each other. The historical claims of the Ecumenical Patriarchate for the sole care of the world diaspora became especially relevant after the Turkish-Greek war. It was then when Fanar lost most of the parishioners due to migration to Western Europe [10, p. 311]. However, this issue remains open at the moment. At the All-Orthodox level (Crete, 2016), the document "Orthodox Diaspora" was adopted, which proposed to conditionally divide the diaspora into 13 regions, which to be governed by interchurch Episcopal meetings [2, p. 61-70]. In fact, this has finally consolidated the existence of "parallel jurisdictions", at least in those countries that have not historically been the area of spread of the Orthodox faith. Although the document itself refers only to the temporary nature of such measures.

It should be noted in this context that the principles of the "canonical territory" of each of the churches have not changed. The existence of "parallel jurisdictions", mainly in non-traditional Orthodoxy-spreading countries, does not contradict the principle of "canonical territory", i.e. the historical jurisdiction of each of the Local Churches. Observance of this ancient law is fundamental for modern Orthodoxy. For example, in polemical speeches and statements related to granting the autocephalous status to the Ukrainian Church, the concept of "canonical territory" has been used very often. Both the Russian Orthodox Church and Fanar expressed their own views, citing various evidence and historical documents, about their own jurisdiction over Ukrainian territory. In particular, the Ecumenical Patriarch has repeatedly stated that: "Ukraine has not ceased to be a canonical territory of the Patriarchate of Constantinople, and has not belonged to the Russian Church."[1]. That is, in order to make any decision in a par- 
ticular territory, it must be under control, within the jurisdiction of a particular church.

To a large extent, Ukraine has become hostage to the concept of "canonical territory". It can be argued that the concept inself was justified by theologians including for the sake of obtaining the Ukrainian territory. After all, the very term "canonical territory" has only recently came into theological usage [4]. It is this concept that prevents the harmonization of relations between Ukrainian churches, and neutralizes all the efforts of Ukrainian society to organize its own Local Church. The speakers of the Russian Orthodox Church, same as its current head, have repeatedly stated that Ukraine is the canonical territory of the Russian Church. The phrase "Canonical Territory" was introduced in modern terminology by Russian theologians in the 90s of the XX century, i.e. when the Soviet Union collapsed. It is obvious that with the proclamation of a new autocephaly, the "canonical territory" of the mother church decreases. The new church takes over jurisdiction within the nation state. It is logical that Russia strives to keep the territory of Ukraine in its own jurisdiction as much as possible, because the recognition of Ukrainian autocephaly by the Russian Orthodox Church will automatically reduce its "canonical territory" of influence.

The principle on which the Russian Orthodox Church theoretical doctrine of "canonical territory" is based is a united beginning one. That is, the canon "one city - one bishop - one church" should come into force. Russia traditionally wants to consider Ukraine as its ownership. However, this approach directly contradicts the 34th well-known apostolic canon, which states that the clergy of every nation (state) needs to know their first hierarch. We state that after the first significant division of the Eastern Church in 451 (Chalcedon), the theory of a united beginning could no longer be implemented in practice. Gradually, a new principle of "parallel jurisdictions" is being formed, which took root in church life in the 20th century with the spread of the diaspora phenomenon. Now in Ukraine there is a stalemate, when two churches operate in parallel. Ukrainian Orthodox Church - Moscow Patriarchate, which is recognized by hierarchy, but not by autonomous status. As well as the Orthodox Church of Ukraine, which gained independent status at the end of 2019, and currently is recognized by only four Local Churches. Representatives of Local Churches have serious complaints not only about the sole procedure for signing the Tomos, but also about the "canonicity" of the clergy. Therefore, in order to better understand the current situation in world Orthodoxy, it is necessary to pay attention to the period of formation of the church tradition and canons.

The principle of managing the early church shows the significant influence of the empire on church administration. At the end of the pre-Nicene period, the administrative structure of the church completely coincided with the territorial division of Byzantium into provinces and regions. According to this division, dioceses were formed, headed by a senior bishop (metropolitan). Church traditions and rules testify to the identity of the borders of the state and the national church. Modern Local Churches received autocephaly on such exact grounds. For example, the boundaries of the jurisdiction of the Polish Orthodox Church coincide with the state border, a similar situation is in Romania and Georgia. It is a bit more difficult, as this issue is currently unresolved at the All-Orthodox level, to understand the situation when the empire is falling apart and the church is claiming the old "canonical territory". Thus, after the collapse of the Soviet Union, the Russian Orthodox Church considers all post-Soviet republics to fall under its jurisdiction, blocking in every way the desire of national churches to obtain autocephalous status. A similar situation developed after the collapse of Yugoslavia. Today, the Serbian Orthodox Church is preventing Montenegro from gaining church independence. However, the late head of the Orthodox Church of the Czech Lands and Slovakia, Archbishop Christopher (Pulec), stated at an international meeting that, after the collapse of Czechoslovakia, their church was not divided [9]. Thus, the question of "canonical territory" and the boundaries of church jurisdiction has put a fork in front of modern ecclesiological church existence. On the one hand, the church authority of the Local Church coincides with the borders of the independent state, as were the cases with new national autocephalies. On the other hand, significant geopolitical changes in the twentieth century have led to a situation where, after the collapse of empires, such as Yugoslavia, the church is in no hurry to give back historically controlled land. This slows down the process of proclaiming new autocephalous churches, such as Montenegrin and Macedonia.

In the historical formation of the modern system of the Ecumenical Church, the institution of autocephaly has significantly influenced the model of relations with the state. Sometimes, the very question of autocephaly decided the vector of relations between states. Thus, from a purely internal, imperial phenomenon, autocephaly has been transformed into a powerful geopolitical factor of international importance. It can be argued that it has become part of diplomacy. Within the empire, the capital's Constantinople chair became the monopolist in matters of church administration, with the support of the emperor. [5, p. 39]. Constantinople chair has played a significant role in the geopolitics of the Balkans and the Middle East for several centuries. A typical example is flirting of the Byzantine Empire with Bulgaria and Serbia. The leadership of these countries rightly considered the autocephalous status of the church to contribute to the formation of political selfsufficiency. Autocephaly from the Ecumenical Chair has become the subject of bidding. It is important to note that it was provided within the borders of the then Bulgaria and Serbia. That is, the "canonical territory" of the newly proclaimed church was to coincide with the borders of state power. A characteristic feature of that period in the history of the church was the granting of autocephalous status exclusively by state authorities, and purely for political reasons. Without the consent of the church, the Senate, headed by Emperor Roman Lecapen, granted Bulgaria autocephaly in the 10th century. King Peter of Bulgaria addressed the Byzantine emperor with a church question. During the Byzantine-Bulgarian War, the emperor singlehandedly revoked the status of the Bulgarian Patriarchate. Thus, we state that from the church-political phenomenon, which it was in the early Middle Ages, autocephaly has been transformed into a purely political phenomenon. [5, p. 39]. It remains so today.

In the new era, the paradigm of autocephaly has changed substantionally. In the XIX century, the "parade of autocephaly" significantly changed the very understanding of this archaic institution. The political identification of entire nations has changed. The collapse of the Ottoman Empire led to the revival of the institution of autocephaly in a new guise. The new Orthodox states that emerged on the map in the early XX century: Greece, Serbia, Bulgaria, Romania, considered their main motive to be fighting with the empire. The path to independence has been lying exclusively through national consciousness. The autocephalous status of their churches greatly contributed to the assertion of their political self-sufficiency. This is where the logic and inner understanding of autocephaly has changed. In the Byzantine era, autocephaly was a deterrent against the 
emergence of new states. It was the mainstay of the empire. And in the new era, autocephaly on the contrary, acted as the identity of the nation, respectively, the imperial allegations were completely denied [5, p. 40]. Due to the events in the Balkans, the Ecumenical Church was forced to come into a period of active reorganization.

It is noteworthy that the role and place of the state in the process of autocephaly has not changed. During the Ecumenical Councils, state power, in the person of the emperor, directly interfered in church affairs. The church became one of the important social institutions of the empire. There are known examples of direct and brutal imperial power management of exclusively religious issues (granting autocephaly to Bulgaria, the arrests of the Patriarchs, etc.). In the new era, again, the state power becomes the initiator of the church movement for independence. It was the governments of the Balkan countries, as well as Poland, that determined the church's status in the international arena. Political pressure on Constantinople led to the autocephalous status of the new national churches.

Thus, the Balkans events actually revived the ancient institution of autocephaly. It was reanimated and adapted to the conditions of modern social life. In the context of the struggle of a number of countries for independence, autocephaly becomes a powerful means of de-imperialization. A striking example is the Polish autocephaly, which demonstrates the struggle of the national government against the newest empire of the Soviet Union.

Summing up, we note that the institution of autocephaly has come a long way. From the basic state of existence, as it was during the early church period, to the church-political phenomenon that it became during the early Byzantium period. In the tenth century, the institution of autocephaly was transformed into a purely political phenomenon, and became the subject of international trade and a significant lever of influence on in the international arena. The revival and new transformation of autocephaly has taken place already in the new era in the Balkans. The territorial principle of autocephaly is changing to a national one. XX century characterizes autocephaly as a means of struggle against the construction of the empire. It determines the cultural and national maturity of the nation. Thus, the church repeatedly invented the institution of autocephaly, and several times rearranged it according to the requirements of the time.

As for the concept of "canonical territory", it directly depends on the definition of the status of a particular church. Autocephaly means self-government of the church in a specific territory. Historically, the church division was formed according to the territorial principle. The boundaries of the first dioceses and metropolitanates coincided with the administrative-territorial division of the empire. Such adherence to the state division is clearly regulated by the canons of the Ecumenical Councils. We can state that the external boundaries of the church are projections of its administrative structures. The church boundaries structure the church organization, providing it with concrete integrity. On the other hand, most modern conflicts between Local Churches arise out of a desire to change these church boundaries. It is to influence the internal as well as external church territories that Russian theologians have proposed a new term "canonical territory" in recent decades. This concept indicates a theoretical sphere of influence on certain lands, that historically belonged to the jurisdiction of a particular Local church. On the other hand, the boundaries of the church need to be critically rethought, because the Church cannot limit itself to the non-Church. The ecclesio- logical nature of the church contradicts the theory of state administration. Thus, the problems indicated in the article are too relevant to address a number of acute issues of modern universal Orthodoxy. Therefore, the chosen topic requires further fundamental scientific research.

\section{Список використаних джерел}

1. Варфоломій: Україна завжди була канонічною територією Константинополя, а не Москви. [Електронний ресурс]. - Режим доступу : https://glavcom.ua/country/society/varfolomiy-ukrajina-zavzhdi-bulakanonichnoyu-teritorijeyu-konstantinopolya-a-ne-moskvi-610107.html.

2. Документи Святого і Великого Собору Православної Церкви (Крит, 2016). - К. : Відкритий православний університет Святої СофіїПремудрості, Вид-во "Дух і література", 2016. - 112 с.

3. Зизиулас Ј., митрополит. Јединство Цркви у святој Евхаристији и у епископу у прва три века / Ј. Зизиулас, митрополит. - Нови сад Беседа, 1997. - 269 с.

4. Иларион (Алфеев), епископ. Принцип "канонической территории" в православной традиции [Электронный ресурс] : доклад на международном симпозиуме на тему "Территориальный и персональный принципы в церковном устройстве" / Иларион (Алфеев), епископ. - Будапешт, 2005. - Режим доступа : https://web.archive.org/bishop.hilarion. orthodoxia.org/1_3_7_2.

5. Кирило (Говорун), архімандрит. Автокесалія та її український варіант. Людина між Церквою і світом: від антагонізму до синергії : мат. міжнар. наук.-практ. конф. / Кирило (Говорун), архімандрит. - Луцьк, 2018. - C. $37-44$

6. Кобетяк А. Еклезіологічна зумовленість автокефального устрою вселенського православ'я // Софрія : гуманіт.-релігієзнавч. вісн. - К., 2020. - № 15. - С. 12-17.

7. Лотоцький О. Автокефалія. Засади автокефалії. - Т. 1. Праці Українського наукового інституту / О. Лотоцький. - Варшава, 1935. - 208 с.

8. Правила Православной Церкви сь толкованіями Никодима, епископа Далматино-Истрійського : у 2 т. - СПб, 1911 (Репринт: Изд. СвятоТроицкой Сергиевой Лавры, 1996 г.). - Т. 1. - 588 с.

9. Христофор (Пулец), архиепископ Пражский и Чешских Земель. Православие в Словакии и Чехии: истоки, современное состояние, перспективы [Электронный ресурс] : доклад "Православие в Европе" / Христофор (Пулец), архиепископ Пражский и Чешских Земель. - Режим доступа : http://orthodoxeurope.org/page/17/18.aspx\#2.

10. A World History of Christianity. Adrian Hastings and contributors. L. : Cassel, Wellington House, 1999. - 594 p.

11. Johnston Hank. Religio-Nationalist Subcultures Under the Communists: Comparisons From the Baltics, Transcaucasia and Ukraine / Hank Johnston // Sociology of Religion. - 1993. -54 , no. 3. - 237 p.

\section{References}

1. Varfolomij: Ukrajina zavzhdy bula kanonichnoju terytorijeju Konstantynopolja, a ne Moskvy. URL : https://glavcom.ua/country/society/ varfolomiy-ukrajina-zavzhdi-bula-kanonichnoyu-teritorijeyu-konstantinopolya-ane-moskvi-610107.html.

2. Dokumenty Svjatogo i Velykogo Soboru Pravoslavnoi' Tserkvy. Kryt, 2016. K.: Vidkrytyj Pravoslavnyj Universytet Svjatoi' Sofii' Premudrosti, DUH I LITERATURA, 2016. 112 p.

3. Zyzyulas J., mytropolyt. Jedynstvo Crkvy u svjatoj Evharystyjy y u epyskopu u prva try veka. Novy sad: Beseda, 1997. 269 p.

4. Ilarion (Alfeev), episkop. Princip "kanonicheskoj territorii" v pravoslavnoj tradicii. Doklad na mezhdunarodnom simpoziume na temu "Territorial'nyj i personal'nyj principy v cerkovnom ustrojstve". Budapesht, 2005. URL : https://web.archive.org/bishop.hilarion. orthodoxia.org/1 3772.

5. Kyrylo (Govorun), arhimandryt. Avtokefalija ta i'i' ukrai'ns'kyj variant. Ljudyna mizh Tserkvoju i svitom: vid antagonizmu do synergii': Materialy mizhnarodnoi' naukovo-praktychnoi' konferencii'. Luts'k, 2018. P. 37-44.

6. Kobetiak A. Ekleziologichna zumovlenist' avtokefal'nogo ustroju vselens'kogo pravoslav'ja. Sofija. Gumanitarno-religijeznavchyj visnyk. № 15. Kyiv, 2020. P. 12-17.

7. Lotoc'kyj O. Avtokefalija. Zasady avtokefalii'. T. 1. Praci Ukrai'ns'kogo naukovogo instytutu. Varshava, 1935. 208 p.

8. Pravyla Pravoslavnoj Tserkvy s' tolkovanijamy Nykodyma, epyskopa Dalmatyno-Ystrijs'kogo: U 2-h t. SPb, 1911. (Reprint: Izdanie Svjato-Troickoj Sergievoj Lavry, 1996 g.) T. 1.588 p.

9. Hristofor (Pulec), arhiepiskop Prazhskij i Cheshskih Zemel'. "Pravoslavie v Slovakii i Chehii: istoki, sovremennoe sostojanie, perspektivy". Doklad. "Pravoslavie v Evrope". № 17. URL : http://orthodoxeurope.org/ page/17/18.aspx\#2.

10. A World History of Christianity. Adrian Hastings and contributors. London: Cassel, Wellington House, 1999. 594 p.

11. Johnston Hank. "Religio-Nationalist Subcultures Under the Communists: Comparisons From the Baltics, Transcaucasia and Ukraine". Sociology of Religion 54, no. 3 (1993). 237 p. 
А. Р. Кобетяк, канд. філос. наук, докторант,

О. Л. Соколовський, д-р філос. наук, доц.

Житомирський державний університет імені Івана Франка, Житомир, Україна

"МЕЖІ ЦЕРКВИ" ТА КАНОНІЧНА ТЕРИТОРІЯ

\section{В КОНТЕКСТІ АВТОКЕФАЛЬНОГО УСТРОЮ ВСЕЛЕНСЬКОГО ПРАВОСЛАВ'Я}

Проаналізовано автокефальний принцип існування церкви. У II-III cm. було сформовано чітку ієрархічну структуру управління церквою. Доведено, що лище автокефальний лад є єдиноприйнятним варіантом існування Вселенського православ'я. Встановлено, що принцип наявності "канонічної території" у кожної із церков постійно порушували. Це пов'язано із проблемою "паралельних юрисдикцій". Межі "канонічної території" мають збігатися із державними кордонами. Хоча на момент інституційного становлення церковні кордони відповідали національним. Територіальний принцип буде сприяти подальшому поділу церков.

Ключові слова: церква, православ'я, канон, собор, митрополит, автокефалія, еклезіологія, діаспора.

А. Р. Кобетяк, канд. филос. наук, докторант,

О. Л. Соколовский, д-р филос. наук, доц.

Житомирский государственный университет имени Ивана Франко, Житомир, Украина

"ГРАНИЦЫ ЦЕРКВИ" И КАНОНИЧЕСКАЯ ТЕРРИТОРИЯ

В КОНТЕКСТЕ АВТОКЕФАЛЬНОГО УСТРОЙСТВА ВСЕЛЕНСКОГО ПРАВОСЛАВИЯ

Проанализирован автокефальный принцип существования церкви. Во II-III cm. была сформирована четкая иерархическая структура управления иерковью. Доказано, что только автокефальный строй является приемлемым вариантом существования Вселенского православия. Установлено, что принцип наличия "канонической территории" в каждой из церквей постоянно нарушали. Это связано с проблемой "параллельных юрисдикций". Границы "канонической территории" должны совпадать с государственными границами. Хотя на момент институционального становления церковные границы отвечали национальным. Территориальный принцип будет способствовать дальнейшему разделению церквей.

Ключевые слова: церковь, православие, канон, собор, митрополит, автокефалия, экклезиология, диаспора

УДК 2-1:323:351 (477)

DOI: $10.17721 /$ sophia.2020.16.4

А. М. Колодний, д-р філософ. наук, проф. Інститут філософрії ім. Г. С. Сковороди НАН України, Київ, Україна ORCID: 0000-0001-8717-9936 e-mail: cerif2000@gmail.com;

Л. О. Филипович, д-р філос. наук, проф. Інститут фрілософії ім. Г.С. Сковороди НАН України, Київ, Україна ORCID: 0000-0002-0886-3965 e-mail: Ifilip56@gmail.com

\section{КОНЦЕПЦІЯ РЕЛІГІЙНОї БЕЗПЕКИ: МЕТОДОЛОГІЧНІ ПІДХОДИ АКАДЕМІЧНОГО РЕЛІГІЄЗНАВСТВА}

Розглянуто методологічні підходи, якими користуються академічні релігієзнавці у процесі формування концепції релігійної безпеки, зокрема України. Завершеної і цілісної стратегії або програми "Релігійна безпека України" поки що не існує, але фахівці активно ведуть їі розробку. Загалом безпеку розуміють як стан, за якого ніхто $i$ ніщо нікому $i$ нічому не загрожує.

Визначено поняття релігійної безпеки України як захищеність свого духовного і релігійного простору від агресії, руйнування, втручання, нав'язування, примушування, корегування тощо з боку інших неукраӥнських структур, організацій, держав, людей, що спрямовані на розмиття та знищення українського світу, зменшення його опірності всім іншим світам.

Докладно проаналізовано зовнішні і внутрішні чинники релісійної безпеки України, що загрожують ї̈ незалежності $i$ самостійності, індивідуальній та колективній ідентичності.

На основі аналізу зроблено висновок про те, що Концепція національної безпеки має містити положення, що забезпечують вільне сповідування віри кожним громадянином Украӥни за умови свободи функціонування релігійних спільнот. Сформульовано ті методологічні підходи українського академічного релігієзнавства, що дозволять вибудувати концепцію, зокрема: 1) світоглядна орієнтація на побудову свого українського світу, який слід розуміти як суспільство, де панують українські цінності, українські візії, конструктивно змінювати пострадянські і російські стереотипи та форми взаємодії між людьми і суспільними структурами на питомо українські; 2) відстоювання цінності релігійної свободи і плюральності релігійного життя в Україні; 3) утвердження відкритості існуючих в Україні релігій, коли та чи інша реліеійна система не замикається на своїй традиції, а відкрита для взаємодії з іншими інституціями як секулярного, так і релігійного світу; 4) практикування нового формату спілкування, який можливий лише через й у формі діалогу: діалогу церкви і держави, церкви і суспільства, церкви і церкви; 5) сприяння державі та ї̈ представникам у впровадженні політики рівності щодо релігійних організацій; 6) покладання на професіоналізм експертів і відповідальність ЗМІ в об'єктивному висвітленні, науковому аналізі та масштабному поширенні інформації про релігійне життя України. Усе це має сприяти пануванню стабільності, прогнозованості, законності, взаєморозуміння і співпраці представників як релігійної, так і державної сфери, як світського, так і релігійного сегментів українського соціуму.

Ключові слова: національні інтереси, релігійна безпека, релігійна небезпека, Україна, релігійні центри, методологічні підходи.

Актуальність. Існує багато видів безпеки/небезпеки - екзистенційна, економічна, екологічна, воєнна, громадська, політична, державна, національна, персональна та колективна тощо. Можна вести мову про інформаційну, правову, наукову, освітню, культурну, гендерну, мовну, харчову, ментальну та фрізичну безпеку/небезпеку. Останнім часом виокремлюють безпеку/небезпеку ре- лігійну, яку нарешті мали б усвідомлювати як важливу складову загальнонаціональної безпеки/небезпеки. На відміну від базових безпек/небезпек, ця досі не визначена ні у спеціальних документах, ні в дослідницькій літературі. Наприклад, у 2019 р. Бюро ОБСЄ з демократичних ініціатив і прав людини (БДІПЛ) оприлюднило документ "Свобода релігій або переконань і безпека: 